\title{
Trade Unionism and Compensation Dynamics: A Research Overview
}

\author{
Indranil Bose* and Baisakhi Mitra Mustaphi ${ }^{\dagger}$
}

\begin{abstract}
Over the years, government's enacted laws and enunciated policies to provide for decent work life, guarantee minimum wages, cushion against rise in cost of living, ensure equal remuneration and deter employers from making unfair and arbitrary deductions from wages has led to a change in the impact trade unions had on wage determination. The present article discusses different aspects of trade union's role in wage and salary administration in terms of choices and options for trade unions, unions' impact on general wage levels, unions' impact in terms of spill-over effect, role of trade unions in wage and salary policies and practices and so on.
\end{abstract}

Keywords: Iron Law Wages, Trade Union, Spill-over Effect, Wage, Salary Policies

\section{Introduction}

The gradual process of withdrawal of the state, the surge of market economy, technological changes and forces of globalisation, specially global production chains and business process outsourcing have resulted in a situation where many started believing that trade union power is weakening. It has been found in

\footnotetext{
* School of Business, University of Bolton, Academic Centre-Ras Al Khaimah, Al HudaibaBareraat, Ras Al Khaimah, United Arab Emirates; sentindranil@gmail.com, sentindranil72@rediffmail.com

† Aditya Institute of Management Studies and Research, Mumbai, Maharashtra, India; baisakhi.m@aimsr.edu.in, bb2.banerjee@gmail.com
} 
the past, when the state pursued welfare policies in many countries, the trade unions considered the state as a dependable ally and started growing. When the state is pursuing a neutral policy, trade unions have become flat and stopped growing. When the state is pursuing policies to attract investors-not necessarily synonymous in all cases with anti union policies-trade union density and their power and influence started declining and weakening.

The rise in union power is almost synonymous with the growth of the modern factory in most cases (Wilson, 2010). The decline in union density and power has become synonymous with the rise in the service sector. In a country like India, traditional service sector is unorganised and non-unionised. Modern service sectorespecially information technology (IT) and information technology enabled services (ITES), retail, private sector insurance, banking and tourism, for instance - and the export sector in special economic zones are either non-unionised or very marginally unionised (Sen, 2009). In the aftermath of dotcom bust in the early years of the $21^{\text {st }}$ century and the recent (2008-09) global meltdown and economic downtown, the cost cutting measures which mostly hurt the working class, the workforce in some of the sectorsspecially IT and ITES saw the need for unionisation not so much for collective bargaining and wage increases as for protection against pink slips and sudden and arbitrary, if not unfair, dismissals (Roy, 2014).

The new generation workforce which is more short term and cash benefit oriented and the growth of female workforce in modern sectors also contributed to a fall in modern density. This is because these groups are generally found to be less prone towards collectivisation and unionisation and they tend to prefer individualisation. The new modern human resource policies in several organisations especially multinational corporations and some private sector firms also favoured treating the new workforce as individuals and began to pursue policies which had the intended and/or unintended effect of reducing unionisation. The new human resource policies usually favoured individual contracts to collective contracts, direct to indirect participation and greater involvement of employees in quality circles, kaizen, 5S and other 
techniques (Singh \& Mayo, 2001). In spite of all these hypes about delegation, decentralisation and devolution of authority and creation of semi-autonomous workplaces through empowerment, Chrys Argaris observed way back in the 1970s that empowerment by and large remained a distant dream (Milkovich et al., 2012).

In addition to the above points, global competitive pressure and the emergence of global production chains have also been responsible for lower-than-normal wage increases in several unionised firms and transfer of jobs from high wage countries to low wage economies. Even the global unions through their solidarity and web based struggles could not prevent these points to a declining power of unions in determining wages and working conditions. Disinvestment, deregulation and decentralisation also contributed substantially to the fall of trade unionism as a bargaining power in favour of the workers (Sen, 2009).

\section{Impact of Trade Unions' on wage determination: traditional and emerging perspectives}

According to Alfred Marshal's 'iron laws of labour', four linkages between the demand for products and the elasticity of demand for labour have been identified. These have been found to be useful for understanding the influence of labour in a given situation. These are technological possibility of substituting other inputs for labour in the production process, the sensitivity of the consumers of the final products to change the prices, the proportion of total costs of a product accounted for by labour costs and the elasticity of supply of other inputs. These four situations, influence trade union matters differently. For example, in industries, where parallel production and outsourcing are possible, unions' position becomes vulnerable likewise in industry, higher customer sensitivity and in many cases subsequent cut throat competitions, trade unions' bargaining power becomes a negative phenomenon. This same factor also contributes to the causes of weakening of trade union power, i.e. fast reduction of the proportion of total costs of a product accounted by labour costs. Elasticity of supply of other inputs also influence bargaining power to a great extent as factors like better technology, abundant supply of labour and so on create a situation more unfavourable against the union's power in many countries 
and industries. Milkovich et al. (2012) have identified few initial factors that can increase the trade unions' ability to bargain; such as taking wages out of competition, control over labour supply and control of skill. According to the same study, the trade unions' demand for specific rate of wage were also based on the ability to live and work (family budget survey), price effect, wage levels (not wage costs), how long to sweat it out for a loaf of bread, source of livelihood and so on. Ratnam, (1989) in his study has highlighted the aspects of trade unions' role in European Union. According to him, the trade unionism has shifted from national to sectoral in most of the countries and any bargaining to settle wage and salaries are determined on the principle of harmonising and social policies on sectoral union involvement basis. Another example has been in the same research in this regard. For example, the institution of global workers' councils which is currently set up in over 100 multinational corporations in the world started the process of sharing and dissemination of information about the impact of business decisions on their human resources and industrial relations practices through a worker representative in each of the locations where they operate. The global workers' councils in large transnational corporations helped coordination of human resource policies across plants in different countries and continents and tried to minimise adverse labour effects except with the explicit consent of trade unions. Singh (2009), in his studies on India has described the situation with historical backgrounds and contemporary trends. According to him, the minimum wage was first discussed in 1958 by Indian Labour Conference (a tripartite body comprising government, trade unions and employer organisations). He highlighted the issues of CPI (Consumer Price Index), national report on minimum wage calculations, trade union participation as bargaining agent over the years and so on. However, studies have also indicated the impact unions have on general wage levels, union involvement in shaping the structure of wage packages, the spill-over effect and role of unions in wage and salary policies and practices.

On the issue of trade union impact on general wage levels, it has been found that unionised workers enjoy higher wage levels in the industries, where trade unions play effective roles in collective bargaining. However, within the same industries, the instances of 
payment of higher wage at a higher level are also not uncommon. According to Bhattacharya (1987), in most of the countries, union density is still at a nascent stage. He has given the example of India, where $93 \%$ of the workforce has been in unorganised sectors at the time of research and the situation has not changed much. He said that more than $87 \%$ of such workers employed in unorganised sector are non-unionised and trade unions based collective bargaining is almost impossible there. Same types of observations can be found in different other researches on developing and underdeveloped nations such as Bangladesh (Chowdhury, 2009), Pakistan (Alam \& Anwar, 2008), Vietnam and Cambodia (Lee and Richard, 2012), different Latin American Countries such as Brazil, Peru, Paraguay and so on (Eskavo \& William, 2007). It has also been found in most of these studies that due to the lack of presence and involvement of the trade unions, there is virtually no collective bargaining existing in the unorganised and even semi- organised industries in majority of these countries. As a result, majority of the workforce in the unorganised sector have remained deprived of minimum wages, social protection and so on. The studies have however highlighted another interesting trend in the respective countries. From the researches, it has been found that the situation is much better in public sectors in almost all the countries, where more than $80 \%$ workforce in general are highly unionised and trade unions have always played significant roles in ensuring much above the minimum wages and social protection of the workers. Most of the above studies have also highlighted that many public sectors in the developing and underdeveloped countries are not only highly unionised but many of them face the situation of multiplicity of trade unionism at the industry, organisation or plant levels. Here, examples have been found, where different trade unions have competed to provide better facilities to the workers and subsequently to attract more members under their folds. Bhattacharya, (1987) in his study has mentioned the examples of trade unionism in private sectors and their impact on worker benefits in some developed nations as well. According to him, some developed countries in Europe have witnessed national level consolidation of trade unionism and such tendencies have made the influence extremely powerful. In his researches, he has further discussed the role of trade unionism in shaping the structure of 
wage packages in Indian industries too. He has shown through empirical investigation that the wage structure issue involves the relationship between workers' wages and what their managers are paid in union and non-union environments. It can be observed that the gap between workers and their managers used to be nearly 20 times in 1970 in the Indian central public sector undertakings. It was reduced to less than 6 times by early 1992. The narrowing of such gap arises because workers' wages go up faster than managers' wages in most of the public sector firms, those were predominantly unionised. The study has also revealed that collective bargaining has also caused the same rise in wages in many private sectors with better trade union standings during the same time. Same has happened in the private firms with executive or managerial trade unionism in one form or other. Richard B Freeman and Joel Rogers (1999), in their works have highlighted the aspects of the spill-over effect and its relationship on wage settlements. In their research, it is said that employers seek to avoid unionisation by offering workers the wages, benefits and working conditions won in rival unionised firms and in the process, the nonunion management continues to enjoy freedom from union 'intervention' in decision making, which is known as 'spill-over effect'. According to their studies, the spill-over effects remained a major factor in many European countries to decide the better compensation without any trade unionised situation. The study by Ratnam (2003), has however addressed the issue from a different rather direct perspective. According to his observation, unionised organisations have been forced in most of the cases in India to raise the compensation bars and wage rates under the influence of collective bargaining. The same study has also shown that such recognition of trade union powers as a bargaining agent has also made the unions to accept managerial rights, substitution of workforce with capital and technology (if required), encouraging greater flexibility and productivity, introduction of new wage administration issues by emphasising more on reward systems and so on. Therefore, in a specific Ratnam's study, trade unionism and its role in wage determination has been covered from a comprehensive all encompassing note. Another study by the Singapore Institute of Labour Studies, (1995) has highlighted the role of trade unions in the wage determination in the situation of 
technological changes in an organisation. The study has further highlighted the trend of giving some benefits; those have not been given earlier, which showed a greater impact on wage determination through direct and indirect inputs from employers as well. The study has identified such inputs such as employers' expenditure on staff training in the situation of technology changes in the organisation, investments on workers' health safety, profit/gain sharing with the employees and so on. The study has given empirical evidence based on panel data which has shown the role of union involvement in Singapore ensuring all these benefits affecting the wage and compensation pattern of the workforce through bargaining and collective negotiation.

\section{Contemporary developments in trade union roles in compensation practices}

With the growing trends of globalisation and international competition, trade unions have been facing an existential crisis in many parts of the world. Ratnakar (2010) in a contemporary study, has highlighted some trends, which have shown the all out efforts by many governments and regulatory authorities to curve the influence of trade unions in recent times. He said that by citing the cases and the apprehensions of losing or driving foreign investors through trade union interferences, many government authorities have even stood with them to ensure lower wages and to establish an environment of non-union situation. However, in spite of such developments, studies by Freeman and Rogers (1999) have shown increasing practices of adopting alternative reward systems in both unionised and non-unionised environments such as lump sum awards, employee stock options schemes (ESOPs), pay for knowledge plans, profit/gain sharing plans and so on. However, their studies have also highlighted the difficulties several countries face regarding the restricted leverage of ownerships of the trade unions in many organisations in many sectors which have made many such alternative plans a limited success. Moreover, the excessive politicisation in the developing world which has proven effective in the developed world in the past has also been highlighted in their studies. This discussion can be concluded here with Rai and Srinivasan's (2009) observation where craft unions 
have been found to be less effective than industrial unions in determining wage levels.

\section{A pilot research}

For the purpose of the present research, a minor survey has been conducted involving 270 employees from Kolkata and Mumbai who have been a part of some trade union or the other for the last 10 years or more at their workplaces. The study has covered employees from 6 major industries, such as banking, insurance, textile, jute, transportation, and engineering. They are still dominated by different trade unions, mainly politically affiliated unions. Based on the past studies, a set of ten questions have been asked and the following replies have been captured (Refer table 1). The responses have been captured on a 5 point Likert scale (1-5), where 1 signifies lowest/least phenomenon and 5 signifies highest phenomenon.

Table 1 (Response pattern)

\begin{tabular}{|c|c|c|c|}
\hline $\begin{array}{l}\text { Q. } \\
\text { No. }\end{array}$ & Question & Mean & $\begin{array}{l}\text { Standard } \\
\text { Deviation }\end{array}$ \\
\hline 1. & $\begin{array}{l}\text { Your trade union association helps you to } \\
\text { directly benefit in terms of compensation }\end{array}$ & 3.7 & 0.98 \\
\hline 2. & $\begin{array}{l}\text { You believe, your present compensation is the } \\
\text { result of trade union role as the bargaining } \\
\text { partner }\end{array}$ & 3.3 & 0.12 \\
\hline 3. & $\begin{array}{l}\text { You believe, non trade unionised employees } \\
\text { at your workplace have also got } \\
\text { compensation benefit due to trade unions also }\end{array}$ & 3.9 & 1.07 \\
\hline 4. & $\begin{array}{l}\text { You believe, non unionised organisations } \\
\text { have also increased the wage of their } \\
\text { employees at the same rate, other unionised } \\
\text { organisations have increased through } \\
\text { bargaining }\end{array}$ & 2.4 & 0.86 \\
\hline 5. & $\begin{array}{l}\text { You believe, non-unionised organisations } \\
\text { have also provided all the benefits to the } \\
\text { employees, which have indirectly impacted } \\
\text { their compensation plan under the influence } \\
\text { of trade unionised organisations }\end{array}$ & 2.9 & 0.07 \\
\hline 6. & $\begin{array}{l}\text { You believe, trade union you represent has } \\
\text { played positive role in ensuring many other }\end{array}$ & 3.3 & 0.19 \\
\hline
\end{tabular}


benefits, those have indirectly and positively impacted your overall compensation.

7. You believe, trade union you represent will be able to better compensation and wage level and structure on regular basis

8. You believe, trade unionism at your workplace/organisation is overall effective in ensuring a competitive compensation environment

9. You believe, trade union/s at your workplace are widely accepted by the employees for protecting their interests

10. You believe, trade union/s are accepted as legitimate power at your workplace by the management.

The above short survey indicates an overall positive role, trade unions' play in different organisations/industries though the analysis can be further done in future on location basis (Kolkata and Mumbai wise), industry basis (banking, insurance, textile, jute, transportation, and engineering). All the ten questions have been framed based on different existing studies such as Rai and Srinivasan (2009) (Questions 7-10), Ratnakar (2010) (Questions 1-4), Bhattacharjee (1987) (Questions 4-7) and so forth. Few observations came up through this pilot survey. It is found that a high level acceptance of trade union at the workplace and a highly favourable opinion for non-union members is getting benefitted through collective bargaining and negotiation between the trade unions and the employer. A generally upper moderate trend in opinion has been found in most of the opinions such as union's role in determining present compensation of the workers, union's role in ensuring other benefits to the employees and so on. Even, the spillover effect related opinion has not been found less favourable.

\section{Conclusion}

Though trade unionism and their legitimacy of involvement in compensation and wage role is growingly facing the challenges for several reasons, still the same has remained moderate to highly relevant in many industries. Ratnam (2003) might have commented 
correctly in his research where the future of compensation at the labour intensive industries have been still related to the trade union power and legitimacy not only in India but also in many foreign countries. Though it would be unfair to be sounding overtly predictable, however, the sharp decline of trade unionism has however been predicted in many studies where individual skill and role based compensation is fast emerging as the trend in capital, knowledge and technology based industries. Trade unionism in influencing the compensation is therefore considered to have reached a significant cross road not only in India but also across the globe. Only the future will be able to predict the dynamics of this very unique but multi-factorial equation in a proper manner.

\section{References}

Alam, S., \& Anwar, A. K. (2008). How trade union is powerful in textile industry in Pakistan? Business Review, 45(1), 461-467.

Bhattacharya, D. K. (1987). Conflict and negotiation in industrial relations. Journal of Industrial Management, 23(2), 2390-2417.

Chowdhury, S. (2009). Power and negotiation - a labour judgement. Bangladesh Research Initiative, 20-31.

Eskavo, S., \& William, R. (2007). Unorganized sector challenges of industrial relations. International Journal of Industrial Psychology, 10(1), 129-140.

Freeman, R. B., \& Rogers, J. (1999). What workers want. Ithaca, New York: ILR Process.

Lee, T., \& Richard, K. (2012). Labour unions and collective bargaining in South Asia. Prince Publications: London.

Milkovich J., Rayn A., \& Thomson. T. (2012). What are the winning formula in collective bargaining? Labour News, $2^{\text {nd }}$ February, 2012.

Rai, A., \& Srinivasan, L. (2009). Trade union dynamics in a corporate world, Journal of Business and Entrepreneurship, Vol. 6(1),418-429.

Ratnakar, C. (2010). Industrial relations, wage administrations and corporate administration, International journal of Labour, Economics and Management, Vol. 17(2), 2009-2020

Ratnam, C. S. V. (2003). Negotiated change: response of collective bargaining to liberalization. Sage.

Roy, S. (2014). New age negotiation in virtual era. ILR Process.

Sen, R. (2009). Industrial relations: texts and cases. India: MacMillan Publishers India Limited.

Singapore Institute of Labour Studies. (1995). Managing organizational change-an overview. SILS Information Series Research Programme, 7-9. 
Singh, A., \& Mayo, T. (2001). How collective is the union bargaining? Journal of Industrial Management, 20(3), 2200-2224.

Singh, S. (2009). Trade unionism: boon or bane? Study report on contemporary industrial relations. Punjab University, India.

Wilson, K. (2010). Emergence of new collectivism in trade unionism. Journal of Applied business, 10(1), 1023-1034. 